\title{
ANALYSIS OF PRE-SERVICE FOREIGN LANGUAGE TEACHERS' INCORRECT ARTICULATIONS: FREQUENCY, INFLUENCE ON COMMUNICATION, AND A SPECIFIC CORRECTIVE STRATEGY
}

PROBLEMS

OF EDUCATION

IN THE $21^{\text {st }}$ CENTURY

Vol. 78 , No. 6, 2020

933

\author{
Coral I. Hunt-Gómez, Macarena Navarro-Pablo \\ University of Seville, Spain \\ E-mail: coralhuntg@us.es,mnp@us.es
}

\begin{abstract}
English Foreign Language (EFL) teachers need to be especially aware of their own articulatory errors and to manage strategies to overcome them. A specific corrective strategy using phonetic notation to destabilise the most recurrent articulatory errors to be applied to Spanish pre-service English Primary School teachers is presented. Firstly, the presence of incorrectly articulated sounds in a corpus of 238 minutes of recorded improvised production of 34 pre-service EFL teachers was identified. Incorrect articulations were classified in two groups, those that presented a higher frequency were classified as fossilised errors and those appearing only once were considered mistakes. A categorisation of the most frequent articulatory errors and their possible origins was offered. Errors were also examined attending the effect they posed on communication, if they hindered it, they were considered unintelligible. Results showed that more than $80 \%$ of fossilised incorrect articulations were perfectly understandable and did not disrupt communication. Even if these results can be considered positive, research shows that pronunciation highly influences the learning process of other skills, and that it affects learners in terms of confidence, social and work advancement. Therefore, to get rid of their own fossilised errors, future teachers need effective pronunciation skills training strategies. For that reason, a specific error corrective strategy based on phonetic notation and self-learning is proposed.
\end{abstract}

Keywords: EFL (English as a foreign language), higher education, second language acquisition, teacher training

\section{Introduction}

An acceptable pronunciation in a foreign language is not only desirable but also one of the skills a fluent speaker should manage, as a grammatically perfect utterance containing pronunciation mistakes can present difficulties to be understood, or even, make the speaker be perceived as less intelligent (Dlaska \& Klekeler, 2008). A good comprehensible pronunciation is thought to help L2 learners to keep improving, as it benefits integration process into the L2 speakers' community (Robertson, 2003) and, as a logical consequence of that integration, L2 speakers improve their communicative competence (Fraser, 1999). Even if it has been proved that pronunciation has an impact in communication and perception, it has been overlooked in most Primary Education schools in Spain (Riquelme Gil et al., 2017). Even if the origin of this situation remains unclear, it can be connected with way L2 which has been traditionally taught in Spain, that is, in an artificial environment using restricted input and without many opportunities for practicing; often without applying any particular pedagogical methodology and without a real communicative purpose. What is undeniable is that, even if the advance of English as a lingua franca has been reflected in the implementation of English-Spanish 
Coral I. HUNT-GÓMEZ, Macarena NAVARRO-PABLO. Analysis of pre-service foreign language teachers' incorrect articulations: Frequency, influence on communication, and a specific corrective strategy

PROBLEMS

OF EDUCATION IN THE $21^{\text {st }}$ CENTURY Vol. 78, No. 6, 2020

934

bilingual programmes in Primary Education Centres, foreign language teachers in Spain still have room for improvement, and, as stated in the scientific literature, this is particularly true when dealing with fossilized errors at a phonological level.

The fact that pre-service Primary teachers, specifically those in their final year inscribed at the English as a Foreign Language specialty, present repeated phonological errors is intriguing and disturbing at the same time. Despite having received linguistic training for more than a decade, the production of these teachers still contains fossilized errors that have not been remedied. This leads to the conclusion that pre-service teachers lack awareness of their own phonological errors as well as strategies to correct them, but it also points to the worrying conclusion that these phonological errors are probably going to be transferred to their future students.

The research had a two-fold aim. First, it was necessary to identify and analyse the most frequent articulatory errors to be applied to Spanish pre-service EFL teachers for them to be aware of their errors. The second aim was to provide them with a specific systematic corrective strategy using phonetic notation to destabilise their errors. For that purpose, the presence of articulatory errors in the improvised oral production of 34 last-year students of the Primary Education degree was corroborated. Incorrect articulations were classified considering different perspectives. From a communicative perspective, two groups were established: unintelligible -hampering-communication- and intelligible-non-hampering communication. From the pedagogical perspective punctual mistakes were differentiated from fossilised incorrect articulations, denominated errors. Highly recurrent fossilised errors were identified and analysed in order to provide possible explanations for their persistence in terms of contrastive articulatory phonetics and communication achievement. This information allowed us to select the appropriate corrective strategy.

The following research questions were addressed: RQ1) Are non-correctly articulated sounds present in Spanish pre-service English Primary School teachers' natural improvised oral production? RQ2) Are they punctual mistakes or persistent fossilised errors? RQ3) What articulatory fossilised errors present a higher frequency? Are there any articulatory errors more frequent than others for Spanish speakers? RQ4) Do they hamper communication? How does communication achievement influence the persistence of fossilised articulatory errors in Spanish pre-service English Primary School teachers' natural improvised oral production? Finally, a proposal for a specific corrective strategy is presented with the double aim to have it applied to the subjects examined as well as to their future students.

\section{Literature Review}

\section{Pronunciation, the Cinderella of EFL Teaching}

Even if pronunciation is generally recognized as an important integrative part of the mastering of a language in the field of EFL teaching, it has been considered a neglected skill. This area has been ignored in many training programmes and teaching materials and in the EFL classroom in general (Baker \& Murphy, 2011; Derwing \& Munro, 2005; Gilner, 2008; Kelly, 1969, p. 87).

Many reasons have caused pronunciation to be overlooked. To start with, pronunciation has received different degrees of attention depending on the teaching method used at a time. In the 70's behaviouristic methods gave way to communicative approaches and consequently, the importance of pronunciation errors lost presence in favour of fluency, rather than accuracy, fostering authentic communicative situations. From the communicative approach, pronunciation was perceived to be more related to accuracy (Breitreutz et al. 2001) and communicative based approaches also favoured a descending pronunciation system, considering aspects such as 
Coral I. HUNT-GÓMEZ, Macarena NAVARRO-PABLO. Analysis of pre-service foreign language teachers' incorrect articulations: Frequency, influence on communication, and a specific corrective strategy

rhythm, stress sentence and intonation (Mompean \& Lintunen, 2015, p. 293). Kelly (2000) attributed this inattention to the fact that teaching pronunciation is a complex matter, which lacks a sound didactic foundation and teaching materials.

Despite being the Cinderella of EFL, from a pedagogical perspective, evidence suggests that pronunciation influences the learning process of other language skills. Learning to listen can be crucial for new methodologies such as Problem Based Learning (Remedios, et al. 2012). In line with this, pronunciation improvement has been considered beneficial to listening ability, as when someone is listening there is a constant assessment of delivery (Underhill, 2005). Goswami (2000), and also Wood and Farrington-Flint (2002) established a link between pronunciation, spelling, and reading proved by orthographic analogies employed when reading, i.e., the ability to read new words applying knowledge used for reading already known words. Likewise, phonological skills also improve spelling abilities, as they make the L2 learner aware of the different sounds. Reading ability has also been related to phonological skills, as phonemic processing strategies are required for reading (Birch, 2011). A recent study concluded that the coordination of auditory and visual components helps EFL learning (Teng, 2019). Reinforcing this statement, Walter (2009) highlighted that comprehension skills are language-independent and that, consequently, they cannot be transferred from native language (L1) to L2. In addition, the researcher claimed that L2 readers achieving good reading comprehension were able to access their already acquired mental structures from the L2 (Walter, 2009).

Another aspect that should be considered from the pedagogical perspective is that pronunciation poses a great deal of influence on learners' confidence. Poor pronunciation can threaten learners' self-confidence and hamper social communication (Morley, 1998). Varasarin (2007) stated that many L2 learners considered pronunciation a matter of importance and wished to receive training. For L2 basic-level students, pronunciation was considered a major barrier when trying to be understood and that had negative consequences on their self-esteem (Brawn, 2010). From a social perspective, pronunciation affects the way in which L2 speakers are perceived as a "poor pronunciation degrades good language skills and condemns learners to less than their deserved social, academic and work advancement" (Varasarin, 2007, p. 45).

\section{Pronunciation and Intelligibility}

It is generally acknowledged that good pronunciation facilitates communication and fosters intelligibility (Varasarin, 2007). Intelligibility may generally be determined by how well a speaker is understood; and, in many occasions, this concept has been directly associated to accentedness, a term coined by Munro and Derwing (1999) to refer to the manner in which a native speaker sounds. Thus, if an L2 speaker aims to be understood in the best possible way, seeking for accentedness may seem the logical option. However, the association between accentedness and intelligibility is not a straight one as it can be influenced by many factors. The most obvious example of influencing factor is the physical conditions of the place where the listener is receiving the input, posing a tremendous influence on intelligibility results (isolation, use of headphones, background noises, etc.). Other factors that may affect intelligibility are the listener's ease of understanding, the influence of the language background, if the listener shares L1 with the speaker and if the listener is aware of the context (Behram, 2017).

It can be stated that a non-native accent is a communication difference characterized by phonetic and phonological features and it systematically differs from those of native speakers (Behrman, 2017, p. 2), yet it may not always affect intelligibility. As intelligibility has been proved to be a complex concept that can be influenced by many factors, throughout this paper, the concept is going to be reduced to its effects on communication.

$\mid \begin{aligned} & \text { PROBLEMS } \\ & \text { OF EDUCATION } \\ & \text { IN THE } 21^{\text {st }} \text { CENTURY } \\ & \text { Vol. } 78, \text { No. } 6,2020\end{aligned}$ 
Coral I. HUNT-GÓMEZ, Macarena NAVARRO-PABLO. Analysis of pre-service foreign language teachers' incorrect articulations: Frequency, influence on communication, and a specific corrective strategy

PROBLEMS

OF EDUCATION

IN THE $21^{\text {st }}$ CENTURY Vol. 78 , No. 6,2020

936

\section{Advanced Learners with Repeated Phonological Errors}

Despite being advanced learners, some speakers present enduring phonological errors in their production in L2 that are incongruent with their other linguistic skills. In order to research this phenomenon, several aspects of Error Analysis (EA) applied to L2 teaching have to be taken into account, as well as the concept of interlanguage, the difference between fossilised and stabilised errors, and their repercussion to teacher training.

Here, it becomes necessary to establish a distinction between mistakes, which are "punctual lapses in the performance", and errors, which are "systematic deviation from a selected norm or set of norms" (Dulay, et al. 1982) that reflects an inadequate competence (Norrish, 1987, p. 7). The analysis of errors in L2 teaching has been widely studied from several perspectives. In the past, teachers considered errors something to be avoided. Applied Linguistics helped this notion evolved, and, from the '70s onward, errors have been treated as indicators of the learners' progress, and are deemed essential for hypothesis testing (Selinker, 1972).

Nearly ten years ago, three practical applications of EA were established: identifying learning strategies; the causes of errors; and common difficulties in order to be dealt with (Richards \& Schmidt, 2010). In this line, during the last decades, studies of L2 acquisition have analysed learners' errors to prevent difficulties in the learning process and design remedial exercises and to focus more attention on problematic features. For that purpose, EA compares errors made in the target language with the target language itself, and also considers possible interferences of the speakers' L1 in the L2 learning process. Ferguson (1965) pointed out that one of the major problems in the learning of an L2 is the interference caused by the structural differences between the native language of the learner and the L2. An interlingual transfer from the L1 to the L2 takes place because the learner's deep knowledge of rules needs to be modified and this modification does not merely affect formal properties but also the way in which the speaker conceptualizes the reality (countable or uncountable nouns, gender assigned to words...), which requires a serious conceptual restructuring (Lucy, 1992).

While this restructuration is taking place, the learner is installed in a stage which Selinker (1972) named interlanguage which "reflects the learner's evolving system of rules, and results from a variety of processes, including the influence of the first language (transfer), contrastive interference from the target language, and the overgeneralization of newly encountered rules" (Cristal, 1997). According to Han (2004, p. 168) transfer is an "an unconscious process, driven by L1-based thinking for speaking systems, whereby the L1 specific way of verbalizing one's conceptualization of experience finds its expression in the interlanguage production and comprehension".

As some aspects from L1 are not positively transferred into L2, in the linguistic state called interlanguage, some new forms in-between L1 and L2 appear, which Selinker (1972) named fossilisations. In 1992, Corder established four different types of stages in the analysis of linguistic transfer; pre-systemic, emerging, systematic, and post systematic. He claimed that only those were to be considered fossilised errors persisting in the discourse of advanced learners, which occur at a post-systemic stage when the system is consolidated, and the learner is fluent and communicatively competent. However, the concept of fossilisation has received different interpretations in the last decades. According to the Fossilisation Hypothesis (Selinker 1972, p. 224), the L2 learning process is inevitably linked to an incomplete command of the language and fossilised units indicate the existence of parallel features in three spheres: the L1, the L2, and the interlanguage. Fossilisation means that a general command of an L2 has not been achieved, and this can occur in different degrees to the same person depending on the situations. Thus, fossilisation has been defined as a generalised phenomenon, based on the influence of L1, which becomes more noticeable when learners are expressing their own thinking (Selinker \& Lakshmanan, 1992). However, as Richards already pointed out in 1971, not all errors in 
Coral I. HUNT-GÓMEZ, Macarena NAVARRO-PABLO. Analysis of pre-service foreign language teachers' incorrect articulations: Frequency, influence on communication, and a specific corrective strategy

L2 are originated by interferences with the speaker's native language; some are caused by overgeneralization (Jakobovits \& Lambert, 1961), ignorance of the rule restriction, incomplete application of rules, false concepts hypothesized or weaknesses or failure of memory.

As in the case of L1 transfer, the germ of fossilisations has also been attributed to restrictions regarding the learner's maturity, instruction or attention; or attributed to the fact that their presence still allows learners to satisfy their communicative necessities. Selinker and Lakshmanan (1992) came to the conclusion that the origin of fossilisation resided in the convergence of multiple factors and that two of them predisposed learners towards it: cognitive maturity and L1 influence. The concept of fossilisation has recently been revised and the result is a more pedagogically oriented definition of fossilisation as "an interlanguage-unique phenomenon in which a semi-developed linguistic form or construction shows permanent resistance to environmental influence and this fails to progress towards the target" (Han 2013, p. 133).

According to Han's definition (2004, p. 170) for an error to be considered fossilised it has to be learnt prematurely, and it has to persist despite the learners' continuous exposition to L2 input, their adequate motivation, and sufficiency of practicing opportunities. Another remarkable feature is that it has been proved that a higher degree of errors occurs when the speaker participates in a natural improvised communicative discourse, identifying what they call L1 thinking for L2 speaking as a possible cause for fossilisation and the frequent asymmetry between L2 production and comprehension (De Keyser, 2005; Ellis 2006; Han \& Lew, 2012; Jiang 2011).

By its definition fossilisation is an irreversible process. However, Han (2011) identified a reversible previous stage that he called stabilisation. He formulated three different stabilisation phases: a natural slowing down in the learning process, an unrecovered restructuration of mental representations, and a fossilisation prelude. This new categorisation supposes an enormous advance in the field of EA and directly affects teachers, as it "enable [s] them to make more effective changes to their practice and achieve better learning outcomes- the goal of L2 education" (Han 2013, p. 165).

\section{EA Applied to EFL Teaching}

One of the main practical results of EA applied to EFL teaching consists of the identification of frequent mistakes among a specific group of learners' production in L2. According to Gutiérrez-Oduber and Miquilena Matos (2009, p. 352), phonetic or phonological are the most frequent type of error in L2 speakers. In their study they amounted for nearly $60 \%$ of the total. In the case of Spanish as EFL speakers, from the EA perspective, several authors have compiled their most frequent errors such as Catford (1987), Coe (1987), Avery and Ehrilch (1992), Gleason, (2012) and Pronunciation (2013). Some of the most recurrent identified errors are confusion between or unawareness of vowel sound articulatory positions, replacing / $/$ by /b/, lack of aspiration of plosive sounds, a tendency to de-voicing at the end of syllables, among others.

Traditionally in oral practice, different ways of correcting errors have been used. The taxonomy created by Lyster and Ranta (1977) covers several of the corrective techniques: recast, elicitation, clarification request, metalinguistic clues, explicit correction and repetition.

Errors are part of the learning process and they allow current and future teachers, not only their identification and correction but also the generation of mechanisms and strategies to overcome them. Different authors have proposed strategies to eradicate errors in L2. Harley (1993) regarded interlinguistic analysis as a helping tool to avoid fossilised errors; Tarone (2000) opted for communication strategies and linguistic games to prevent fossilisation through the destabilisation of the interlanguage and Johnson (1992) created a specific pedagogical strategy

OF BDUCATIO

IN THE $21^{\text {st }}$ CENTURY

Vol. 78 , No. 6, 2020

937 
Coral I. HUNT-GÓMEZ, Macarena NAVARRO-PABLO. Analysis of pre-service foreign language teachers' incorrect articulations: Frequency, influence on communication, and a specific corrective strategy

PROBLEMS

OF EDUCATION IN THE $21^{\text {st }}$ CENTURY Vol. 78, No. 6, 2020

to help those advanced learners with fossilised errors improve. In a more updated analysis, Pavón Vázquez (2001, p. 112) suggested strategies for those errors that are susceptible to be corrected by means of instruction.

In 2015, Mompean and Lintunen explored the potential advantages of the use of phonetic notation in language teaching and learning, and results showed that its use was perceived positively by a majority of learners in terms of raising awareness of the L2 pronunciation features and favouring autonomous learning. This initiative of applying phonetic notation in EFL teaching and learning presents an excellent opportunity to develop a methodology to destabilise errors in $\mathrm{L} 2$.

In the field of teacher training, despite Henderson (2013) denouncing insufficient teacher phonological training in Europe; in the Spanish university system, in the Degree of Primary Education students receive intensive phonological and pronunciation related training because pronunciation is considered to be an essential part of the L2 curriculum and a fundamental skill for the teaching practice. However, pre-service teachers do not have the tools to apply the received phonological training (Gilbert, 2010).

Han's (2013, p. 165) recommendations for the analysis of learners' phonetic mistakes using a corpus include the recordings of improvised situations in which students create their discourse in a way that shows their real competence in communicative contexts, that is, the study goes beyond sentence-levels and include contextualized, natural, discourse data.

\section{Research Methodology}

\section{General Background}

This research is based on an emerging design in grounded theory (Creswell, 2012, p. 433), as data were collected and immediately analysed with the aim of establishing a categorisation of actual errors in a descriptive way. Even if the nature of video-recordings allowed the researchers to be unobtrusive by not being present, an observational protocol was applied. Three experts analysed the corpus and identified those sounds that were not correctly uttered, then, classified them as intelligible or unintelligible. The three of them were EFL teachers with more than 10 years of professional experience and a vast knowledge on phonetics. According to the classification made by Bravo, et al. (2009), this study applied a prospective ex-post fact methodology, as the interdependent variables cannot be manipulated and are to be studied to determine their degree of influence. The research took place at the end of the year 2019.

\section{Sample}

A corpus of 238 minutes of improvised discourse was analysed. The corpus consisted of the improvised oral production collected from 34 participants. 27 participants were women and 7 men. All participants were Spanish native speakers. They were final-year students of the Degree on Primary Education in the University of Seville during the academic year 20182019. All subjects participated voluntarily, and their data were anonymised. Every participant produced a lesson in English that lasted from 5 to 10 minutes. The lessons were recorded which resulted in a corpus of recorded oral improvised production of 238 minutes, which corresponds to the duration of the video recording.

\section{Instrument and Procedures}

The aforementioned corpus was viewed, and the incorrectly articulated sounds were identified. Three different expert researchers performed data analysis and management. 
Coral I. HUNT-GÓMEZ, Macarena NAVARRO-PABLO. Analysis of pre-service foreign language teachers' incorrect articulations: Frequency, influence on communication, and a specific corrective strategy

PROBLEMS

OF EDUCATION

IN THE $21{ }^{\text {st }}$ CENTURY

Vol. 78 , No. 6, 2020

According to articulatory phonetics, they were divided into two main groups: vowels and consonants. Once located, incorrectly articulated sounds were categorised following two of the possible classifying ways established by Vazquez (1991, p. 21): pedagogical and communicative. From a communicative perspective they were classified according to the effect they posed on communication, those hampering communication were classified as unintelligible, and those not hampering it were considered intelligible. From a pedagogical perspective and for the purpose of the analysis, the frequency of the same incorrectly articulated sound was a decisive feature, as only those errors that were present more than once were considered recurrent stabilised errors.

\section{Data Analysis}

Collected data were statistically analysed. Means and standard deviations were calculated with the purpose of identifying those articulatory fossilised errors that presented a higher frequency. In order to contrast the differences between unintelligible and intelligible utterances, a Chi-square test was performed.

\section{Research Results}

Those incorrectly articulated sounds that were present more than once were considered recurrent stabilised errors. The results show a compendium of 19 recurrent stabilised errors selected exprofeso and categorised in two different groups according to articulatory phonetics: vowels, and consonants (Tables 1 and 2, respectively). In the first place, the frequency of errors was analysed.

\section{Table 1}

Errors (vowels)

\begin{tabular}{|c|c|c|}
\hline & $\mu$ & $S D$ \\
\hline $\mid æ /$ & 0.53 & 0.74 \\
\hline |al & 1.12 & 0.84 \\
\hline$|a:|$ & 0.59 & 0.85 \\
\hline $13: \mid$ & 1.03 & 0.87 \\
\hline li:/ & 0.59 & 0.78 \\
\hline $10: /$ & 0.53 & 0.82 \\
\hline lu:/ & 0.44 & 0.66 \\
\hline /eI/ & 0.44 & 0.74 \\
\hline |ail & 0.24 & 0.55 \\
\hline /абə/ & 0.24 & 0.49 \\
\hline /əo/ /av/ lea/ & 0.35 & 0.73 \\
\hline /ju:/ & 0.50 & 0.86 \\
\hline$|\mathrm{p}|$ & 0.24 & 0.55 \\
\hline$|\mathrm{s}|$ & 1.06 & 0.95 \\
\hline
\end{tabular}

\section{Table 2}

Errors (consonants)

\begin{tabular}{ccc}
\hline & $\boldsymbol{\mu}$ & $\boldsymbol{S D}$ \\
\hline$\nabla \mathrm{s} / /$ & 0.15 & 0.43 \\
$/ \mathrm{v} /$ & 1.21 & 0.91 \\
$/ \mathrm{Z} /$ & 0.82 & 0.90 \\
$/ \mathrm{t} / / \mathrm{S} /$ & 0.35 & 0.69 \\
De-voicing at the end of syllable & 1.97 & 1.62 \\
\hline
\end{tabular}


Coral I. HUNT-GÓMEZ, Macarena NAVARRO-PABLO. Analysis of pre-service foreign language teachers' incorrect articulations: Frequency, influence on communication, and a specific corrective strategy

PROBLEMS

OF EDUCATION

IN THE $21^{\text {st }}$ CENTURY

Vol. 78, No. 6,2020

Of those 19 errors, five present mean higher than 1: three vowels and two consonants. The sounds /a /, /3:/ and $/ \Lambda /$ for the vowels and devoicing at the end of syllable and mispronouncing the sound $/ \mathrm{v} /$ for the consonants.

Following Vázquez (1991, p. 21) communicative criteria, errors were categorised in two groups. Table 3 shows the statistics for the intelligible and the unintelligible, the mean of the intelligible being very superior. Chi-square for 1 degree of freedom is equal to 26.354, corresponding to a level of significance of $p<.001$, so with a confidence level of $99.9 \%$, there are statistically significant differences between the number of the intelligible and unintelligible utterances.

Table 3

Errors Categorised according to the Communicative Criteria (Vázquez, 1991, p. 21).

\begin{tabular}{cll}
\hline & Intelligible & Non-intelligible \\
\hline$\mu$ & 11.50 & 2.82 \\
$S D$ & 6.354 & 3.672 \\
$\Sigma$ & 391 & 96 \\
$\%$ & 19.1 & 80.29 \\
\hline
\end{tabular}

\section{Discussion}

Results provided by the present study regarding the presence of phonological errors in advanced learners gave rise to several findings already observed by the researchers due to their experience as teacher trainers assessing students' oral production for many years. To answer RQ1, the hypothesis that advanced learners with an adequate English command present recurrent errors at a phonological level is confirmed by the errors identified in the sample. Spanish pre-service teachers of English with an intermediate-high command of the language in other skills presented recurrent errors in their natural improvised speech, mostly at a phonological level. This is consistent with previous research on the field of Second Language Acquisition (Gutiérrez Oduber \& Miquilena Matos 2009, p. 352). Regarding RQ2, a clear difference was established between errors that happened once, that were considered punctual mistakes and those at a phonological level that were repeated, that were considered persistent fossilised errors and therefore central to this research.

The results provided by this distinction lead to RQ3, that was to identify the most recurrent errors of pre-service teachers that have a good command of the English language in improvised natural situations. The identified errors can be described as partially consistent with the classifications regarding common pronunciation errors among Spanish speakers of English in the previously examined literature. Nonetheless, the corpus analysis shows 19 recurrent types of errors, from which five obtained a frequency rate higher than 1 and they were analysed in detail in terms of articulatory phonetics and from both a communicative and a pedagogical perspective.

The first type of articulatory error is vowel pronunciation. Unlike English, which is normally referred to as an opaque language, Spanish is considered a transparent one (Meschyan \& Hernandez, 2006). Also, according to the classification of vowels in these two languages created by Finch and Ortiz-Lira (1982, p. 35), in Spanish, there are no central vowels. The higher frequency of errors in the vowels $/ \mathrm{a} /, / 3: /$ and $/ \mathrm{N} /$ (see Table 1 ) can be explained by the fact that they are central and are not included in the Spanish phonological system, thus Spanish speakers have a tendency to substitute them by close sounds they are familiarized with. Similarly, one of the most recurrent pronunciation errors found is substituting the /a/ sound for 
Coral I. HUNT-GÓMEZ, Macarena NAVARRO-PABLO. Analysis of pre-service foreign language teachers' incorrect articulations: Frequency, influence on communication, and a specific corrective strategy

PROBLEMS

OF EDUCATION

IN THE $21^{\text {st }}$ CENTURY

Vol. 78 , No. 6,2020

another vowel based on spelling. For example, when pronouncing about /o'bavt/, the first /a/ will be substituted for another vowel sound closer to the ones included in the Spanish phonetic system such as /a/ or /a:/. As the /a / sound is the most common vowel in oral English, the impact off a non-desirable pronunciation is to be considered. Another error which presented a very high frequency was the vowel/3:/. As in the previous case, the mispronunciations consisted of substituting the sound for another spelling based on the way they would be pronounced following the Spanish phonetic system. Examples of this can be the pronunciation of words such as first /f3:st/ in which the vowel is substituted for the sound /i/ or word /w3:dz/ in which the sound is substituted by the sound $/ \mathrm{O} /$. In the case of the $/ \mathrm{N} /$ sound, it was substituted in most cases by another vowel based on the spelling of the Spanish system.

The remaining errors which present a mean higher than one are linked to the incorrect pronunciation of consonants, specifically replacing the /v/ sound by /b/, not being the grapheme $\mathrm{v}$ articulated as voiced in the Spanish phonological system, in opposition to what happens in the English one; and de-voicing consonants at the end of the syllable (see Table 2). Negative transfer can be the origin of these repeated errors. In Spanish, the grapheme $v$ is pronounced as /b/. Errors consisting of devoicing in word endings, which according to the studied literature is a common error among Spanish native speakers when communicating in English, can also possibly be influenced by a particular characteristic of Southern Spain, an extremely evolved realization of consonants in syllable coda position (Moreno-Fernández, 2004; Villena-Ponsoda, 2008, p. 144).

Once these errors have been identified, a strategy to defossilise them by using phonological notation is presented suggested. It is a double aimed strategy: firstly, it is helping future teachers to correct their own stabilised errors and, the second one consists on transferring the use of this methodology to their future profession and, in that way helping their prospective students to overcome phonetic stabilisation. Therefore, they could use this technique in their classes.

The literature analysis undertaken here has provided a deeper insight into fossilised errors and stabilised ones. The most obvious finding to emerge from this study is that errors are part of the learning process and that L2 students need to activate strategies and tools to overcome them. Consequently, the relevance of awareness in the L2 learning process has been proved to be paramount. If errors are not consciously identified and dealt with, they can become fossilised and negatively affect not only the L2 learning process but also the EFL speaker self-esteem and social or work-related aspects.

Considering RQ4, recurrent errors were categorised considering their effect on communication, i.e., if they hampered communication or not. 80 ' $21 \%$ errors did not seriously affect communication. Therefore, only a minority of the errors analysed hampered communication, 96 out of 391 (Table 3). According to the studies on intelligibility discussed on the section Pronunciation and Intelligibility, this result can be influenced by the circumstances, the knowledge of the speaker's first language that the listener has, among many other factors. Nonetheless, overall, these results indicate that only a reduced percentage of errors (19'71\%) affected communication negatively.

Together, these results provide important insights into the recurrence and persistence of errors at a phonological level in advanced learners of EFL. However, the lack of correction of recurrent mistakes can be due to the fact that they do not hamper communication, as previous research indicates (Behram, 2017). Even if communication can occur when the speaker presents phonological mistakes, poor pronunciation can negatively affect social, academic or workrelated advances for that particular speaker (Brawn, 2010) or damage that person self-esteem (Morley, 1998). 
Coral I. HUNT-GÓMEZ, Macarena NAVARRO-PABLO. Analysis of pre-service foreign language teachers' incorrect articulations: Frequency, influence on communication, and a specific corrective strategy

PROBLEMS

OF EDUCATION

IN THE $21^{\text {st }}$ CENTURY

Vol. 78, No. 6, 2020

942

Pedagogical Implications and Suggestions

Several implications for pronunciation teaching and destabilisation of mistakes in L2 can be drawn from the results discussed in the previous section. The first one is that good phonological training for teachers and EFL learners can be very useful in order to raise awareness regarding pronunciation problems. Recent research has focused on how to deal with the persistence of phonetical errors in advanced learners and ways of improving pronunciation in a foreign language (Mompean \& Lintunen, 2015; Riquelme Gil, et al., 2017; Simon, et al. 2015). The most recent study encourages phonetic transcription combined with reading aloud to raise learners' awareness of their own pronunciation (Riquelme Gil et al., 2017, p. 17), which adds to the benefits provided by reading aloud claimed by previous researchers, such as strengthening grapho-phonemic correspondences of the L2, regardless the complexity of the orthographic system (Lázaro Ibarrola, 2011). In 2015, Mompean and Lintunen researched the potential advantages the use of phonetic notation has to language teaching and learning and examined the learners' perception of their own pronunciation after applying it.

In this study, a detailed strategy for destabilising errors at a phonetic level is described. The strategy encourages learners to be aware of their own mistakes and provides them with specific stages to overcome their fossilised errors in an uncomplicated and autonomous way.

The implementation of the strategy is illustrated in six steps. In the first one, the learner has to listen to a recording of a natural oral intervention and write it down including its full transcription (Figure 1).

\section{Figure 1}

Script from Student's Production

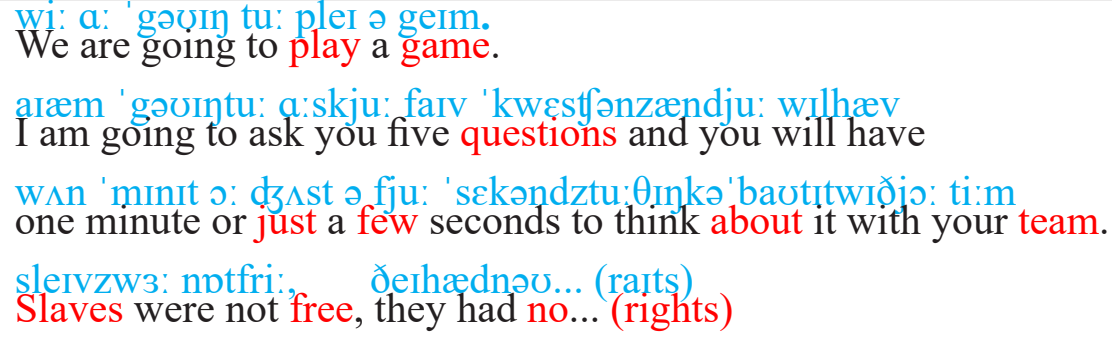

The second stage consists of reading the transcription of the oral intervention aloud and identifying those words that the learner has mispronounced. Phonetic notation plays the role of helping the students being aware of their articulation errors. After years using this strategy in our classroom, most students get extremely surprised when they read texts together with their transcriptions and they find out that they mispronounced familiar and/or frequent daily used words. From a pedagogical point of view, this is a crucial stage. Students develop awareness about the existence of these type of errors and they become prepared to use their knowledge on phonetic notation in order to improve their overall oral speech.

In the third stage, the phonetic transcription is only maintained on top of those words or sounds that were not correctly pronounced and the mispronounced words are marked in a different colour (see Figure 2). The reduction of phonetic transcription has the aim of facilitating the reading process. 
Coral I. HUNT-GÓMEZ, Macarena NAVARRO-PABLO. Analysis of pre-service foreign language teachers' incorrect articulations: Frequency, influence on communication, and a specific corrective strategy

\section{Figure 2}

We are going to play a game.

'kwesţonz

I am going to ask you five questions and you will have

dzast fju: a'bavt ti:m

one minute or just a few seconds to think about it with your team.

sleivzfri:, nəv... (raits)

Slaves were not free, they had no... (rights)

In the fourth step, the learner reads aloud the text with the help of the phonetic notation and records it. Learners are to listen to the recording and progressively eliminate the transcription in those words that are correctly pronounced. This step can be repeated as many times as required (Figure 3). Repetition at this stage is important since it is proved to be quite effective as corrective feedback.

\section{Figure 3}

Fourth Step

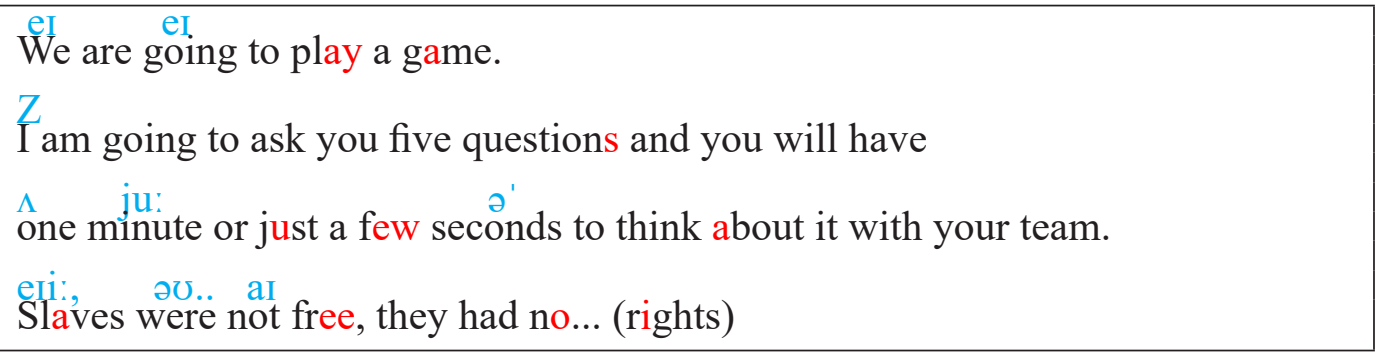

In the fifth stage, the supporting phonetic transcription is not maintained and only the words or sounds that are being destabilised are marked in a different colour, as a warning sign which helps the students to avoid reading the text paying attention to the spelling. Learners are to listen to the recording and progressively eliminate the marks in those words or sounds that are now correctly pronounced. This step can be repeated as many times as required (Figure 4).

\section{Figure 4}

Fifth Step

We are going to play a game.

I am going to ask you five questions and you will have

one minute or just a few seconds to think about it with your team.

Slaves were not free, they had no... (rights)

Once all errors have been overcome and the correct pronunciation has been acquired, all marks are to be removed from the text. Finally, the text is to be read aloud, recorded, and the final recording without mispronunciations to be listened to. 
Coral I. HUNT-GÓMEZ, Macarena NAVARRO-PABLO. Analysis of pre-service foreign language teachers' incorrect articulations: Frequency, influence on communication, and a specific corrective strategy

PROBLEMS

OF EDUCATION IN THE $21^{\text {st }}$ CENTURY Vol. 78 , No. 6, 2020

944

\section{Conclusions and Implications}

A good intelligible pronunciation is, in general, desirable for every L2 speaker. It has been proved that it not only makes the speakers' utterances intelligible, but also favours integration and even can be beneficial in social and work spheres.

Despite its positive influence on the learning of other skills been proven, pronunciation has not been given a prominent place in EFL Teaching in Spain in Primary Education. Consequently, pre-service schoolteachers for EFL in Spain, besides most of them having an upper-intermediate level of English language and phonological knowledge, present a lower level in pronunciation skills. This means that they need strategies and techniques to improve their own pronunciation skills and to help others to improve theirs.

One of the main conclusions that can be driven from the results of this research is that, in most cases, a poor pronunciation does not hinder communication. This might be the reason why pre-service teachers present recurrent pronunciation mistakes, as they are able to produce comprehensible output with no evidence of communication breakdown, from a communicative perspective. From a pedagogical perspective, another possible reason might be that they lack awareness regarding their own fossilised mistakes. This is a major problem that emphasizes the need for further research. This becomes especially relevant in the case of EFL teachers since pronunciation errors can be transferred to their future students and, therefore, they need to identify them and to master strategies and techniques to destabilised them.

The relatively small size of the data set means that it is not possible to generalise the results concerning recurrent stabilised errors and make them extensible to all Spanish learning EFL. However, the error taxonomy was created using a sample from a consistent group and, therefore, some errors are expected to be present in subjects with similar characteristics. Future teachers need to be familiarised with the possible causes of frequent errors, to be aware of the complexity of the learning process and of the difficulties encountered by learners of different native languages. Based on this taxonomy, a specific phonetic notation with a corrective strategy is proposed. It can be used to overcome pre-service EFL teachers' fossilised pronunciation errors as well as the ones of their future students.

Despite its exploratory nature, this piece of research adds to the growing body of literature that highlights the importance of good phonological training for teachers in order to be able to apply and provide strategies and methodologies to overcome stabilisation in the phonological level. A natural following of this work would be to analyse the progression of students using the suggested methodology and to determine its efficiency.

\section{References}

Avery, P., \& Ehrlich, S. (1992). Teaching American English pronunciation. Oxford University Press.

Baker, A. A., \& Murphy, J. (2011). Knowledge base of pronunciation teaching: Staking out the territory. TESL Canada Journal, 28(2), 29-50. https://doi.org/10.18806/tesl.v28i2.1071

Behrman, A. (2017). A clear speech approach to accent management. American Journal of SpeechLanguage Pathology, 26(4), 1178-1192. https://doi.org/10.1044/2017_AJSLP-16-0177

Birch, B. (2011). Out of my orthographic depth: Second language reading. In E. Hinkel, E. (Ed.), Handbook of research in second language teaching and learning (pp. 488-507). Routledge.

Brawn, J. R. (2010). Teaching pronunciation gets a bad R.A.P.: A framework for teaching pronunciation. Hankuk University of Foreign Studies.

Breitkreutz, J. A., Derwing, T. M., \& Rossiter, M. J. (2001). Pronunciation teaching practices in Canada. TESL Canada Journal, 19(1), 51-61. https://doi.org/10.18806/tesl.v19i1.919

Catford, J. C. (1987). Phonetics and the teaching of pronunciation. In J. Morley (Ed.), Current perspectives on pronunciation: Practices anchored in theory (pp.87-100). Teachers of English to Speakers of Other Languages Incorporated (TESOL). 
Coral I. HUNT-GÓMEZ, Macarena NAVARRO-PABLO. Analysis of pre-service foreign language teachers' incorrect articulations: Frequency, influence on communication, and a specific corrective strategy

Creswell, J. W. (2012). Educational research: Planning, conducting, and evaluating quantitative and qualitative research (4th Ed.). Merrill.

Crystal, D. (1997). A dictionary of linguistics and phonetics (4th Ed.). Blackwell.

Coe, N. (1987). Speakers of Spanish and Catalan. In M. Swan, \& B. Smith (Eds.) Learner English: A teacher's guide to interference and other problems. (pp. 90-113). Cambridge University Press.

Colás Bravo, M. P., Buendía Eisman, L., \& Hernández Pina, F. (2009). Competencias científicas para la realización de una tesis doctoral. [Scientific competences to create a doctoral thesis]. Davinci.

Corder, S. P. (1992). Introducing applied linguistics. Penguin.

DeKeyser, R. M. (2005). What makes learning second-language grammar difficult? A review of issues. Language Learning: A Journal of Research in Language Studies, 55(S1), 1-25. https://doi.org/10.1111/j.0023-8333.2005.00294.x

Derwing, T. M., \& Munro, M. J. (2005). Second language accent and pronunciation teaching: A researchbased approach. TESOL Quarterly, 39(3), 379-397. https://doi.org/10.2307/3588486

Dlaska, A., \& Krekeler, C. (2008). Self-assessment of pronunciation. System, 36(4), 506-516. https://doi.org/10.1016/j.system.2008.03.003

Dulay, H. C., Burt, M., \& Krashen, S. (1982). Language two. Oxford University Press.

Ellis, N. (2006). Selective attention and transfer phenomena in SLA: Contingency, cue competition, salience, interference, overshadowing, blocking and perceptual learning. Applied Linguistics, 27(2), 164-194. https://doi.org/10.1093/applin/aml015

Ferguson, C. A. (1965). General introduction to contrastive structural series. The University of Chicago Press.

Finch, D. E., \& Ortiz-Lira, H. (1982). A course in English phonetics for Spanish speakers. Heinemann Educational Books.

Fraser, H. (1999). ESL pronunciation teaching: Could it be more effective? Australian Language Matters Journal, 7(4), 7-8.

Gleason, J. (2012). Beaches and peaches. Common pronunciation errors among L1 Spanish speakers of English. In J. Lewis, \& Levelle, K. Proceedings of the $3^{\text {rd }}$ Pronunciation in Second Language Learning and Teaching Conference (16 ${ }^{\text {th }}-17^{\text {th }}$ September 2011, Iowa, USA) (pp. 1-11). Iowa State University.

Gilbert, J. (2010). Pronunciation as orphan: What can be done? IATEFL Pronunciation Special Interest Group Newsletter, NN, 1-5. https://www.tesol.org/docs/default-source/new-resource-library/ pronunciation-as-orphan-what-we-can-do-about-it-.pdf?sfvrsn=0

Gilner, L. (2008). Pronunciation: A review of method and techniques. Journal of School of Foreign Languages, 35, 93-108. https://core.ac.uk/download/pdf/235011992.pdf

Goswami, U. (2000). Phonological representations, reading development and dyslexia: Towards a cross-linguistic theoretical framework. Dyslexia 6(2), 133-155. https:// doi.org/10.1002/(SICI)1099-0909(200004/06)6:2<133::AID-DYS 160>3.0.CO;2-A

Gutiérrez Oduber, O. I., \& Miquilena Matos, R. J. (2009). Retroalimentación oral correctiva en el aula de Inglés como Lengua Extranjera (ILE) [Oral corrective feedback in the English as a foreign language classroom]. Laurus, Revista de Educación, 15(29), 339-367.

Han, Z. H. (2004). Fossilization in adult second language acquisition. Multilingual Matters.

Han, Z. H. (2011). Fossilization-A classic concern of SLA research. In Gassand, S., \& Mackey, A. (Eds.), The Routledge handbook of second language acquisition (pp. 476-490). Routledge.

Han, Z. H. (2013). Forty years latter: Updating the fossilization hypothesis. Language Teaching, 46(2), 133-171. https://doi.org/10.1017/S0261444812000511

Han, Z. H., \& Lew, W.M. (2012). Acquisitional complexity: What defies complete acquisition in SLA. In B. Szmrecsanyi, \& B. Kortmann (Eds.) Linguistic complexity in interlanguage varieties, L2 varieties, and contact languages. (pp. 192-217). Walter de Gruyter.

Harley, B. (1993). Instructional strategies and SLA in early French immersion. Studies in Second Language Acquisition, 15(2), 245-259. https://doi.org/10.1017/S0272263100011980

Henderson, A. (2013). The English pronunciation teaching in Europe survey (EPTiES): Initial results and useful insights for collaborative work. In E. Waniek-Klimczak, \& L. Shockey, (Eds.), Teaching and researching English accents in native and non-native speakers. (pp. 123-140). Springer Verlag. 
Coral I. HUNT-GÓMEZ, Macarena NAVARRO-PABLO. Analysis of pre-service foreign language teachers' incorrect articulations: Frequency, influence on communication, and a specific corrective strategy

PROBLEMS

OF EDUCATION IN THE $21^{\text {st }}$ CENTURY Vol. 78 , No. 6, 2020

946

Jakobovits, L.A., \& Lambert, W.E. (1961). Semantic satiation among bilinguals. Journal of Experimental Psychology 62(6), 576-582. https://dx.doi.org/10.1037/h0042860

Jiang, N. (2004). Morphological insensitivity in second language processing. Applied Psycholinguistics 25(4), 603-634. https://doi.org/10.1017/S0142716404001298

Johnson, H. (1992). 'Defossilizing?, ELT Journal, 46(2), 180-189. https://doi.org/10.1093/elt/46.2.180

Kelly, G. (2000). How to teach pronunciation. Longman.

Lucy, J. A. (1992). Grammatical categories and cognition: A case study of the linguistic relativity hypothesis. Cambridge University Press.

Lázaro Ibarrola, A. (2011). Imitating English oral texts: A useful tool to learn English pronunciation? Porta Linguarum, 16, 49-63.

Lyster, R., \& Ranta, L. (1977). Corrective feedback and learner uptake: Negotiation of form in communicative classrooms. Studies in Second Language Acquisition, 19(1), 37-66. https://doi.org/10.1017/S0272263197001034

Meschyan, G., \& Hernandez, A. E. (2006). Impact of language proficiency and orthographic transparency on bilingual word reading: An fMRI investigation. NeuroImage, 29(4), 1135 1140. https://doi.org/10.1016/j.neuroimage.2005.08.055

Mompean, J. A., \& Lintunen, P. (2015). Phonetic notation in foreign language teaching and learning: Potential advantages and learner's views. Research in Language, 13(3), 292-214. https://doi.org/10.1515/rela-2015-0026

Moreno-Fernández, F. (2004). Cambios vivos en el plano fónico del español: variación dialectal y sociolingüística. [Live changes in the phonetic sphere in Spanish: Dialectal and sociolinguistic variation] In R. Cano (Ed.), Historia de la lengua española [Spanish language History]. (pp. 9731009). Ariel.

Morley, J. (1998). Trippingly on the tongue: Putting serious speech/pronunciation instruction back in the TESOL equation. ESL Magazine, 1(15), 20-23.

Munro, J. M., \& Derwing, T. M. (1999). Foreign accent, comprehensibility, and intelligibility in the speech of second language learners. Language Learning, 45(1), 73-97. https://doi.org/10.1111/0023-8333.49.s1.8

Norrish, J. (1987). Language learning and errors. Macmillan Publisher.

Pronunciation Studio (2013, December 3). 10 English Pronunciation Errors by Spanish Speakers. https://pronunciationstudio.com/spanish-speakers-english-pronunciation-errors/

Pavón Vázquez, V. (2001) La incidencia de los procesos de desarrollo en la creación de la fonología de una segunda lengua [Impact of the development processes in phonology creation of a second language]. ELIA: Estudios de Lingüística Inglesa Aplicada, 2, 105-114.

Remedios, L., Clarke, D., \& Hawthorne, L. (2012). Learning to listen and listening to learn: One student's experience of small group collaborative learning. Australian Educational Researcher, 39(3), 333348. https://doi.org/10.1007/s13384-012-0064-x

Riquelme Gil, I., Roca de Larios, J., \& Coyle Balibrea, Y. (2017). The effect of repeated reading on the pronunciation of young EFL learners. Porta Linguarum, 27, 7-19.

Robertson, P. (2003). Teaching English pronunciation skills to Asian learner. A cultural complexity or subsumed piece of cake? Asian EFL Journal, 5(2), 1-26.

Richards J. C., \& Schmidt, R. (2010). Dictionary of language teaching and applied linguistics, (Fourth Edition). Longman.

Selinker, L. (1972). Interlanguage. Product Information International Review of Applied Linguistics in Language Teaching, 10, 209-241. http://dx.doi.org/10.1515/iral.1972.10.1-4.209

Selinker, L., \& Lakshmanan, U. (1992). Language transfer and fossilization: The 'multiple effects principle'. In S. Gass, and L. Selinker, (eds.) Language transfer in language learning. (pp. 197216). Benjamins.

Simon, S., Kilyeni, A., \& Suciu, L. (2015). Strategies for improving the English pronunciation of the $1^{\text {st }}$ year "Translation-Interpreting" students. Procedia- Social and Behavioural Sciences, 191(2), 2157-2160. https://doi.org/10.1016/j.sbspro.2015.04.222

Tarone, E. (2000). Getting serious about language play: Language play, interlanguage variation and second language acquisition. In B. Swierzbin, et al. Social and Cognitive Factors in SLA: Proceedings of the 1999 Second Language Research Forum (15 ${ }^{\text {th }}$ September 2000, Minnesota, USA) (pp. 31-54). Cascadilla Press. 
Coral I. HUNT-GÓMEZ, Macarena NAVARRO-PABLO. Analysis of pre-service foreign language teachers' incorrect articulations: Frequency, influence on communication, and a specific corrective strategy

PROBLEMS

OF EDUCATION

IN THE $21^{\text {st }}$ CENTURY

Vol. 78 , No. 6, 2020

Teng, F. (2019). Incidental vocabulary learning for primary school students: the effects of L2 caption type and word exposure frequency. The Australian Educational Researcher, 46, 113-136. https://doi.org/10.1007/s13384-018-0279-6

Underhill, A. (2005). Sound Foundations: Learning and Teaching Pronunciation (2 ${ }^{\text {nd }}$ Ed.). Macmillan Education.

Varasarin, P. (2007). An action research study of pronunciation training, language learning strategies and speaking confidence [Doctoral dissertation, Victoria University]. http://vuir.vu.edu.au/1437/

Vázquez, G. E. (1991). Análisis de errores y aprendizaje de español/lengua extranjera [Error analysis and Spanish/foreign language Learning]. Peter Lang.

Villena-Ponsoda, J.A. (2008). Sociolinguistic patterns of Andalusian Spanish. International Journal of the Sociology of Language, 193/194, 139-160. https://doi.org/10.1515/IJSL.2008.052

Walter, C. (2009). Teaching phonology for reading comprehension. IATEFL Pronunciation Special Interest Group Newsletter, 40, 4-7.

Wood, C., \& Farrington-Flint, L. (2001). Orthographic analogy use and phonological priming effects in non-word reading. Cognitive Development, 16(4), 951-963. https://doi.org/10.1016/S08852014(02)00071-0

Received: September 18, 2020

Accepted: December 01, 2020

Cite as: Hunt-Gomez, C. I., \& Navarro-Pablo, M. (2020). Analysis of pre-service foreign language teachers' incorrect articulations: Frequency, influence on communication, and a specific corrective strategy. Problems of Education in the 21 $1^{\text {st }}$ Century, 78(6), 933-947. https://doi.org/10.33225/pec/20.78.933

\begin{tabular}{|c|c|}
\hline $\begin{array}{l}\text { Coral I. Hunt-Gómez } \\
\text { (Corresponding author) }\end{array}$ & $\begin{array}{l}\text { PhD, Lecturer, Department of Language Education, University of Seville, C/ } \\
\text { Pirotecnia s/n, Sevilla, 41013, Spain. } \\
\text { E-mail: coralhuntg@us.es } \\
\text { ORCID: https://orcid.org/0000-0001-6261-927X }\end{array}$ \\
\hline Macarena Navarro-Pablo & $\begin{array}{l}\text { PhD, Lecturer, Department of Language Education, University of Seville, C/ } \\
\text { Pirotecnia s/n, Sevilla, 41013, Spain. } \\
\text { E-mail: mnp@us.es } \\
\text { ORCID: https://orcid.org/0000-0003-1954-0851 }\end{array}$ \\
\hline
\end{tabular}

